\title{
THREE ASPECTS OF THE PHENOMENON OF SCIENCE: IN SEARCH FOR UNITY AMONG SOCIOLOGISTS
}

\author{
N. G. Popova' ${ }^{1}$ E. V. Biricheva ${ }^{2}$ \\ Institute of Philosophy and Law, Ural Branch of the Russian Academy of Sciences, \\ Ekaterinburg, Russia. \\ E-mail: ${ }^{1}$ ngpopova@list.ru; ${ }^{2}$ e.v.biricheva@mail.ru
}

\section{T. A. Beavitt}

Institute of Philosophy and Law, Ural Branch of the Russian Academy of Sciences, Ekaterinburg, Russia; The 'Global Village Bard' Organisation, Russia - UK.

E-mail: tommy@globalvillagebard.org

Abstract. Introduction. In today's globalising world, science acquires a crucial importance: integrating humanity within the framework of solving global problems, it becomes one of the leading factors in social development, facilitating work and diversifying leisure time, as well as serving as an instrument of transformations in the political sphere. Undoubtedly, the social aspects of contemporary science are capturing the attention of a huge number of researchers. However, it is not clear that all areas of the sociology of science treat the object of their study in the same way.

Aim. A lack of reflection on the unity or otherwise in the understanding of the essence of science in the various fields of sociological research makes it difficult to compare different theories of the institutional, cultural, social and communicative contexts of scientific development. An urgent methodological task therefore consists in developing an understanding of the various definitions of the concept of "science" used in the framework of contemporary sociological analysis of this phenomenon.

Results and scientific novelty. In this paper, two dominant sociological views on science - as an experimental-mathematical approach to cognising the world and as a system of representations in general - are compared. We conclude that while researchers studying institutional aspects of science tend to interpret it in terms of the "heritage" of post-Enlightenment European rationalism, constructionist and communicatively-oriented researchers tend to approach science as the system of knowledge and cognition that is formed in any human society, having its own specific sociocultural features in each respective case. While each of these two approaches undoubtedly has its own methodological potential, in order to 
provide such a diverse field of studies with a common ground, it would be necessary to balance them with a third aspect. We argue that this balancing role, since both common for all mankind and unique for every culture, could be played by Heidegger's conceptualisation of science as "the theory of the real".

Practical significance. In order to avoid a pluralism of incompatible theories, it is important to continually pose the question "what is the object of study when conducting a sociological study of various scientific phenomena?" - as well as to understand the "limits of applicability" of the particular interpretation of science on which basis sociological analysis proceeds.

Keywords: sociology of science, social institutions of science, generation of scientific knowledge, concept of science, philosophy of science, experimental and mathematical knowledge, knowledge system, theory of the real.

For citation: Popova N. G., Biricheva E. V., Beavitt T. A. Three Aspects of the Phenomenon of Science: In Search for Unity among Sociologists. The Education and Science Journal. 2018; 9 (20): 35-55. DOI: 10.17853/1994-5639-2018-9-35-55

\title{
ТРИ АСПЕКТА ФЕНОМЕНА «НАУКА»: ПОИСК ЕДИНСТВА СРЕДИ СОЦИОЛОГОВ
}

\author{
Н. Г. Попова ${ }^{1}$ Е. В. Биричева ${ }^{2}$ \\ Институт философии и права Уральского отделения Российской академии \\ наук, Екатеринбург, Россия. \\ E-mail: ${ }^{1}$ ngpopova@list.ru; ${ }^{2}$ e.v.biricheva@mail.ru
}

Т. А. Бивитт

Институт философии и права Уральского отделения Российской академии наук, Екатеринбург, Россия; "The 'Global Village Bard' organization,, Россия; Соединённое Королевство Великобритании и Северной Ирландии.

E-mail: tommy@globalvillagebard.org

Аннотаиия. Введение. В современном глобализующемся мире научные знания приобретают все большую значимость: они интегрируют усилия человечества для решения общих проблем, становятся одними из ведущих факторов развития общества, облегчают труд и разнообразят досуг Аюдей. Кроме того, они используются и в качестве инструмента социально-политических трансформаций. Не случайно сегодня внимание огромного количества исследователей приковано к социальным аспектам науки, а также образования как важнейшего взаимосвязанного с ней социального института.

Однако вопрос о том, все ли направления социологии науки трактуют объект своего изучения одинаково, остается открытым. Между тем практически полное отсутствие рефмексии по поводу единства в понимании существа 
науки в поле социологических исследований затрудняет сопоставление размичных теорий развития научного знания в институциональном, культурном, социально-коммуникативном контекстах. Такое положение дел актуализирует поиск решения одной из центральных методологических задач по осмыслению вариантов опредемения понятия "наука", используемых в рамках современного социологического анализа данного феномена.

Цель публикации заключается в попытке сопоставить основные трактовки науки - как экспериментально-математического способа познания мира и как системы представлений о существующих реалиях.

Результаты и научная новизна. В ходе обсуждения проблемы авторы приходят к выводу о том, что исследования, посвященные изучению институциональных аспектов, тяготеют к пониманию науки как рационалистического "наследия" Европы Нового времени, а конструкционистски и коммуникативистски ориентированные течения склонны рассматривать ее как систе-

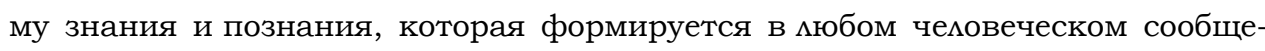
стве, имея, однако, в каждом случае свои специфические социокультурные черты. Каждое из двух указанных направлений, несомненно, обладает своим методологическим потенциалом. Тем не менее в целях выведения таких разноплановых исследований на единую почву предлагается уравновесить их третьей точкой зрения, согласно которой наука есть "теория действительного", имеющая черты универсально-общечеловеческого и уникально-культурного феномена.

Практическая значимость. Ответ на вопрос: "Что мы изучаем, когда проводим социологическое исследование науки?" позволит избежать плюрамизма несопоставимых теорий и понять "границы применимости" той трактовки науки, от которой мы отталкиваемся в социологическом анализе.

Ключевые слова: социология науки, институты науки, генерация научного знания, понятие науки, философия науки, экспериментально-математическое познание, система знаний, теория действитецьного.

для иитирования: Попова Н. Г., Биричева Е. В., Бивитт Т. А. Три аспекта феномена "наука": поиск единства среди социологов // Образование и наука. 2018. Т. 20. № 9. С. 35-55. DOI: 10.17853/1994-5639-2018-9-35-55

\section{Introduction}

In today's globalising world, social aspects of the phenomenon of science, including its institutional specificity and the laws governing the generation of scientific knowledge, have become one of the leading subjects of research across a wide range of sociological disciplines, including social psychology, social philosophy, social epistemology, ethics and scientometrics. However, it is not entirely clear that it is the same "science" that is being 
studied in all cases. Evidently, even among prominent sociologists and philosophers of science, there continues to be a lack of unity on this issue. For example, Bruno Latour, through the activity of "following around" [1] the practitioners of science, focuses solely on the representatives of natural and technical sciences (STEM ${ }^{1}$ ), whereas Michel Foucault, in excavating the "archaeology of knowledge", examines the foundations of the historical transformation of socio-cultural codes on the example of the humanities [2]. And if Latour's theory lacks applicability to the social organisation of philosophical and social humanitarian studies, as well as being limited in terms of its time frame to the contemporary stage of "big science", Foucault's conclusions, by contrast, are productive for understanding the developmental patterns of the system of knowledge and cognitive toolkit in general, since being formed on the ground of variously contrasting cultural and historical locales.

When surveying the field of contemporary sociology of science, what can be observed about the different interpretations of science? The positions of Robert Merton's well-known "ethos of science" [3] and the "Matthew effect" [4] are based on ideas derived from Western rationality. In his epistemological research, David Bloor rediscovers the world of culture and the "social component" standing between the knowing subject (cogito) and the object of knowledge [5, pp. 18, 28]; accordingly, the formation of scientific knowledge across different historical epochs necessarily varies. From a neo-Marxist position, Jürgen Habermas shows how science and its technical applications have become a new ideology, facilitating the manipulation of mass consciousness by extending the promise of a comfortable, secure existence [6]. In his analysis of the organisation of a contemporary university, Steve Fuller remarks on the entrepreneurial nature of contemporary social knowledge production [7] (see also [8]). Then, can all these diverse research approaches be discussing the same "science"? Or is it rather the case that actor-network theory, structural functionalism, social constructionism, interactionism, communicativism and other areas of contemporary sociology of science each start from a different understanding of the phenomenon of science?

While it may not be appropriate to speak about a pluralism of concepts of science in this field, it is evident that different aspects of the sociological study of science may be distinguished. Moreover, in focusing on empirical material, researchers often fail to elucidate their basic understanding of science, in the light of which they nevertheless propose a development model, a classification of types of knowledge or a scheme of social management. This,

${ }^{1}$ Science, Technology, Engineering, and Mathematics.

Образование и наука. Том 20, № 9. 2018/The Education and Science Journal. Vol. 20, № 9. 2018 
of course, complicates an attempt to compare different positions, as well as raising the question of the truth value of any knowledge generated. The more controversies swirl around problems concerning the production of scientific knowledge, publication ethics and the historical transformation of science, as well as cultural conditionality, social and communicative aspects, etc. [9-22], more important it becomes to understand what we have in mind when we are talking about science. In this context, the necessity for a methodological systematisation of the conceptualisations of "science" being actively used by contemporary researchers becomes clear. In this paper, however, rather than setting out to find the most "correct" definition of science or striving to provide a common denominator to existing definitions (science as knowledge production, cognitive process, means of achieving practical benefits, type of cultural activity, social and institutionalised phenomenon, way of achieving truth, educational level, branch of knowledge, etc.), we aim to highlight a possible ground of unity capable of supporting interpretations that define the essence of contemporary science. In this vein, two understandings of science are compared: (1) science as an emergent phenomenon reflecting the essence of Western rationality; and (2) science as continuum of social phenomena inherent to - and determined by - the specific culture in which they are manifested. By way of a conclusion, a third approach is proposed in which differences between these two understandings are partially resolved, with science being seen a human activity resulting in a theoretical representation of reality.

\section{First aspect: Science as the heritage of post- Enlightenment Western European thought}

When posing the question of when science became what it is today - with its empiricism, mathematisation and unprecedented penetration into all spheres of society - the Enlightenment foundations of contemporary European thought are never far away. The consideration of science in the light of such rationalistic bases typically begins with Immanuel Kant, who pointed out that, by the turn of the 17th century, mathematics had already been established as the fundamental language of naturalistic description and experiment as the preeminent method for revealing knowledge [23, p. 99-124]. Reflecting on the historical development of science, Kant makes the following observations:

1. All previous eras, beginning with Ancient Egypt and Greece, are conceived as preparatory stages for the scientific rationality of the Modern era; in other words, sciences are developing in a movement from unsystematic observations and random experiments to a more ordered system of knowledge, i.e. in a progressive direction (Kant even observes that "mathematics was left 
groping about for a long time" [23, p. 107]). In this connection, it is notable that the majority of subsequent thinkers consider science precisely in terms of that progress and ordering that brings humanity closer to true knowledge.

2. The revolutions that periodically occur in the sciences are thus seen as virtues that lead to breakthroughs in revelation of the truth [23, pp. 107109]. The perception of the development dynamics of science as taking a revolutionary and / or saltatory form is prevalent in most related concepts within the philosophy of science today.

3. According to Kant, the primary science, towards which all natural sciences should be oriented, is mathematics, since this form of knowledge is constructed entirely a priori in the mind, based on pure contemplations in and of space and time [23, p. 107]. Thus, natural sciences should proceed on the model of mathematics, constructing hypotheses and working through their implications by means of experiments [23, p. 109].

From the late 19th through into the 20th century, positivists and neoKantians continued the Kantian approach in the philosophy of science, considering its development in terms of "from the lowest to the highest". This was also facilitated by the dissemination of the ideas of historicity and evolutionism inherent in the philosophical concepts of Georg Hegel, Karl Marx and Charles Darwin. In addition, the lightning-fast successes of the technical application of the scientific achievements of the 17th-18th centuries so decisively overshadow the achievements of previous periods that the existence of science as a holistic phenomenon is only acknowledged from the 17th century onwards (see also [24]).

Significantly, Kant warns against constructing social sciences and humanities in the image and likeness of natural science, since sciences concerned with the life of the human soul cannot have the same methods as those whose object of study is nature [23, p. 115-117; 25]. Nevertheless, the pursuit of a non-dual picture of the world, supported by practical advances in the exact sciences, formed new ideals and resulted in the positivistic approach becoming increasingly popular [26]. Thus, already by the beginning of the 20th century, mathematical methods of cognition were beginning to be applied in social humanitarian studies, having significantly pushed back against descriptive and intuitive-analytical approaches. As a result, despite the criticisms of this interpretation from phenomenological quarters $[27 ; 28$, p. 6], most contemporary researchers still rely on an understanding of science as the experimental-mathematical method of rational cognition of the world that arose in the Modern era. 


\section{Second aspect: Cultural specificity of science as a system of knowledge}

The aforementioned understanding of science as a recent phenomenon having arisen in the European context raises a reasonable question about the Eurocentrism of science as such [29]. In the contemporary world, not everyone agrees with the majority position of Western researchers; this disagreement may be expressed in the laconic phrase of Hans-Georg Gadamer "the scientific character, in the name of which we ask our questions, is itself a Western invention" [30, p. 27]. Thus, representatives of other cultures may reasonably object that those integral elements on which basis contemporary Western culture asserts its primacy had already arisen in other cultural and historical contexts long before the 17th century. For example, mathematics, astronomy, chemistry and pharmaceuticals were being developed in Ancient Egypt and Mesopotamia between 6000 and 4000 BC. Similar examples can be cited from the history of ancient China and India, Arab countries and the civilisational empires of the Americas. Such historical facts concerning scientific knowledge and the technological achievements of a number of different civilisations against the background of the globalisation processes of the 20th century led many thinkers, including Westerners, to consider science as a phenomenon that arises in human culture, taking distinct conceptual and methodological forms in different societies. Clearly, it would be impossible to base an identification of such cultural-historical specifics on a narrow understanding of science as logically-formalised mathematical-experimental research, the methodology of which is determined by strict adherence to the principle of sceptical doubt in everything, which supposedly lies at the basis of contemporary European rationality [31].

Thus, the simultaneous appeal to science both as a culturally-conditioned phenomenon and as a universal form of activity common to all mankind foregrounded the need to search for an alternative unified basis for its understanding. Researchers drew attention to the similarity of conscious structures and cognitive processes of all human beings, regardless of their ethnic, social and cultural identity [32]. However, the uniformity of structures of consciousness reproduced on different cultural substrates cannot become a criterion for the unity of science as a universal phenomenon, since, on the one hand, not all conscious (and unconscious) activity is reducible to scientific functions, and on the other, the content of scientific knowledge differs in different societies.

In this respect, an interesting interpretation of the grounds of science was proposed by Michel Foucault in line with the postmodern idea of the dis- 
cursivity of a given culture. By questioning the accepted schemes of understanding science as a type of human activity based on the principles of logic, objectivity and rationality, Foucault traces the conditioning of scientific knowledge and scientific methodology to the type of culture in which knowledge is formed. The very formulation of the question of science as a culturally-conditioned activity becomes possible only in the light of a meeting with the Other - in a broad sense, an encounter with a different culture and a different way of thinking [2, pp. xvi-xxvi]. Foucault supposes that scientific knowledge is formed through the innate predisposition of humankind towards order. The thinker refers to this order as having its basis in the "episteme", i.e. a structure that functions as a means of organising cognitive practices. However, prior to the orders of different cultures and types of representations, there must be a fundamental order of reality that a person is not able to comprehend. Consequently, each order of representation remains incomplete and its inadequacy, when subjected to enquiry, is eventually revealed. Therefore, Foucault claims, it is not possible to say that science develops in a linear progression; rather, cultural-historical epochs are incomparable, since each develops according to its own epistemic structure.

However, it was not only postmodernists like Foucault who were engaged in understanding science as characteristic of any particular society, but at the same time reflecting its cultural specificity and approaches to cognition. Many other notable thinkers have also remarked on the apparent fact that, along with rational processes, knowledge creation is often accompanied by irrational moments (intuition, insight), [33-36]. Indeed, even in the light of the understanding of science as an objective type of human activity relying on logical rules and empirical methods, it is still impossible to ignore the individual researcher's own subjective vision. After all, the selection of the object and the methodology of a study is necessarily dependant on the individual researcher's axiological guidelines and ethical attitudes, as well as on the forms of social organisation of science and the international political situation as it affects the particular society within which he or she works. In other words, this set of factors is entirely coloured by the cultural specificity of the individual researcher. Within the framework of this interpretation, science may be understood - along with art, philosophy and religion - as a culturally-specific type of human activity.

Nevertheless, despite the methodological potential gained from considering science as a cultural phenomenon, in comparison with a rationalistic understanding, this interpretation lacks unity and clarity. The reason for this may be seen in the multiple interpretative permutations inherent in the con- 
nection between science and history, civilisation and culture. By the same token, to try to apply a unique unifying definition of these concepts would present a huge - and probably unsolvable - problem. Moreover, due to the desire for inclusiveness, this perspective is forced to deal with the paradox of knowledge and cognition. Any knowledge implies a certain fixity of the actual state of affairs and the concomitant collapsing of meaning into the form of a model. However, stable knowledge - for example, concerning the essence of motion (distinct from knowledge about how particular bodies move) - is fundamentally unattainable (this ancient paradox also was noted by the ancient Greek thinkers Parmenides and Zeno). Along with the fundamental impossibility of fixing dynamic aspects of reality in the course of cognition, universality is also impossible as a consequence of human finitude. Since "everything" comprises an infinite set of unique things and processes, this infinity cannot be mastered by finite lives: at least, not by looking at the beginning of everything, since everything always already happened as it did and not as it didn't (see also [37]). Finally, within the framework of a culturally-specific view of science, it is difficult to solve the problem of demarcating the scientific from the unscientific. Each culture not only develops its own standards for determining the truth value of knowledge - as well as its own research methods and the corresponding forms knowledge takes - but also institutionalises cognitive activity into that culture's intrinsic structures. Consequently, even when located far from the "traditional" (Eurocentric) understanding of scientific knowledge, the scientific knowledge and cognitive activity of a given culture should be considered on an equal footing with all others.

\section{Third aspect: Science as "the theory of the real"}

Comparing the two aforementioned sociological views of science, let us consider what is the fundamental property without which an activity cannot be described as "science". Firstly, it is important to note that the two abovementioned aspects of the understanding of the essence of science are not simple oppositions of views; rather, they reveal an underlying paradox. Despite their contrasting focal points, both positions view science as a holistic phenomenon - at the same time universal, since each participant aims at creating knowledge, and in particular, since the content-specificity of all scientific research is affected by the unique culture, social structure and mentality of the researcher. Thus, in carrying out research activities, representatives of quite distinct cultures are nevertheless able to comprehend each other as being involved in the same kind of work, as being cognisant of a common world on the basis of a number of varying existential grounds, but fol- 
lowing the same laws of the working of human consciousness, which, by its very nature, is capable of abstracting, generalising, discerning patterns in chaos; that is to say, thinking theoretically.

By taking a phenomenological approach, it may possible to approach a finer distinction between science and non-science, since here it is we ourselves as researchers who undergo the experience of science. For this purpose, we may analyse with what (1) and how (2) science deals when forming knowledge:

1) Science deals with reality-based objects. On the one hand, science is not limited to what is directly apprehended by human perception but is also capable of making an object of study of that which in the ordinary sense cannot be said to exist (black holes, hole-type conductivity, the absence of verbal forms for some tenses in some languages, etc.) or the indiscernible as in the contradictory object of the human state (for example, the feeling expressed by an artist, which serves as the object for an observing psychologist). On the other hand, science occupies itself only with what is real. In this connection, even virtual reality is to some extent real, because it is part of our reality and influences it; consequently, such sciences as computer science, psychology or sociology are of no lesser interest to the scientist than natural reality. At the same time, scientists do not admit winged horses or fire-breathing dragons into reality other than in their capacity as objects of folklore in philology or aesthetic imagery in the study of art.

2) Science deals with its objects by representing them (i.e. by placing them in front of itself). Whether it is a physician examining an individual patient, a chemist observing a particular reaction, a botanist studying a distinct variety of chamomile, etc., these phenomena are only subject to the interpretation of scientists as a consequence of the latter already having an idea about the human body generally, about chemical reactions generally, about the corresponding type of plants generally, etc. Thus, science deals with the unique only in terms of a variation in the embodiment of the universal. Moreover, the universal (general) turns out to be more important for science than the unique (individual), with which everyone can only deal separately in his or her own "empirical" way. Even psychology, in its capacity as the "science of the soul", only studies individual psychic phenomena to the extent that they conduce to deducing the general laws that are common to the functioning of any psyche. Even the study of unique events taking place in history or particular works of art is aimed at highlighting the general in each particular example (for example, the repetitive "mechanism" of revolution or the characteristic painting technique of a particular era or artist). 
In other words, in highlighting the subject matter of reality for its study, science "sets it out" in front of itself, examining unique phenomena in order to identify features common to the series in which they are manifested. In order to apprehend the universal, it is necessary to present the objects in the light of theory, not just recreating the images, but as if weighing them against known forms. Between the researcher and the object of knowledge, appears a "screen" of generalised theoretical representation, which abstracts (isolates) the unique by imposing a constructed universal form onto it. According to Merab Mamardashvili, "it is only in the light of theory that something can have the value of an empirical fact, a clear empirical basis for our knowledge, with which they must necessarily correspond" [38, p. 75]. Thus, each concrete and unique horse is recognised in empirical experience precisely as a "horse" in terms of its abstract form (eidos, category, universal) and is studied in the sciences through the prism of many such universal conceivable forms: as a species for a zoological researcher, as an organism for a veterinarian, as an image reproduced in a painting for an art historian, etc.

In the theoretical space delineated by such universal forms, science also works out its own idea of reality, by means of which activity knowledge is formed. In this case, the knowledge reflects the design, schema or model of a real object, but not the object itself in its entirety. From a number of each-time-unique phenomena, science takes a unique snapshot of the universal. In this way it becomes clear why science, in contrast to other forms of cognition, tends towards mathematical language: if a number represents the ultimate abstraction, then the ultimate appears in the general, which may be represented by a series of completely discrete objects. As Werner Heisenberg wrote, "a comparison of, say, three cows with three apples indicates their common characteristic, namely the one that is expressed by the word "three" [39, p. 242]. Martin Heidegger speaks about the same thing: science, at least in its contemporary form, comprises the "picture of the world", its presentation in the theoretical space and "universal scheme" of phenomena, i.e. "science is the theory of the real" [40, p. 157].

This definition of science is rooted in the ancient Greek word $\theta \varepsilon \omega \rho i a$ (theory), which can be translated as "mental contemplation". The connection between science and ancient Greek philosophy was formed during Antiquity, when, in line with the mentality and ontological intuitions of the Greeks, there was an understanding of the need and usefulness of special practices of mental contemplation. At that time, scientific knowledge was separated from unscientific $\delta \dot{\delta} \xi a$ (opinions) [41] and purely practical activities, which were not supported by a theoretical "knowledge of causes" [42]. However, the an- 
cient Greek origin of the word "theory" does not imply that the view of science as a theorising activity is derived solely from the traditions of the ancient European world. On the one hand, it is undoubtedly the case when being guided by such a criterion that the epochs of Antiquity, the Middle Ages and the Renaissance possessed their own distinct forms of science. On the other hand, the development of the theoretical component and the allocation on this basis of scientific knowledge within the framework of social institutions (scientific schools, communities of spiritual practitioners, priests) allows us to recognise the existence of science outside of Western cultural localities. Thus, it seems possible to say that, while science has developed on all continents in parallel with European history, in the current situation it is becoming increasingly obvious that science has its own socio-cultural specifics in different countries.

\section{Conclusion}

As is shown, the phenomenon of "science" can be interpreted in different ways:

1. On the one hand, it comprises a method of cognition based on the laws of logic and experimental evidence, striving for mathematical precision in the formulation of rational laws. This is the science that originated in Western Europe at the turn of the 16th-17th centuries and continued to develop in its non-classical and post-non-classical variations. Thus, in their substantive focus on the study of the institutional organisation of research, a number of sociological approaches are based on the functional qualities of the elements of social and scientific subsystems. The use of mainly mathematical, statistical and quantitative methods allows researchers to model the processes and trends of social interrelationships of scientists in the context of differences in accepted norms and ideals applying to scientific work, drawing conclusions about the dependence of the nature of production of scientific knowledge on the systemic features of the functioning of the scientific community and developing management recommendations for adjusting the relevant systems. At the same time, society and the laws undergirding its existence are considered, in essence, by analogy with biological systems and the functioning of the organism, in which the sociological studies of the structural-functionalist are likened to the natural sciences both in terms of the initial set-up and the specific quantitative methodology used. This limits the application of the research approach to "Western" science and its systems of organisation at the same time as prohibiting the application of this methodology to the study of the social existence of science affecting various types of cul-

Образование и наука. Том 20, № 9. 2018/The Education and Science Journal. Vol. 20, № 9. 2018 
tures at macro-social scales). This feature also explains the interest of researchers into this trend being mainly limited to the social existence of the natural and technical sciences, which more closely meets the criteria of rationality and empirical verifiability of the results of scientific activity.

2. On the other hand, science can be understood as the quintessential form of human activity, consisting in the construction of knowledge about the world and its application in practice. While such science exists in any cultural and historical locality, it can be loaded with mystical, mythological, religious and ideological contents. Contemporary researchers are in a position to classify such knowledge as unreliable. Nevertheless, it can be seen that belief in a knowledge system allows a person to derive benefit and signification from it, which is arguably more important for that person than the criteria of objectivity and rationality. In these circumstances, neither experimentation, mathematisation nor objectification can be regarded as unmistakable signs of science. Being based on such a broad understanding of science, constructivist and communicatively-oriented sociological concepts focus their attention primarily on the production of scientific knowledge. The construction of scientific knowledge implies, on the one hand, an inevitable appeal to the social communication environment, in which context the ways of generating ideas about reality are established, and on the other, to a study of the distinctive features of the actors (participants) of these design processes. However, due to excessively broad interpretations of this conceptual corpus of science, knowledge, society, communication and language, questions arise concerning the initial "driving forces" of knowledge generation and its connection with the organisational forms taken by scientific activity, the boundary blurring effect applying to interlocutors in the area of communication, as well as the problem of demarcating science from other forms of cultural practices (ideological, mythological, religious, philosophical, etc.). As a result of the predominance of qualitative and descriptive research methods, based predominantly on textual analysis, as well as considering the cultural and linguistic knowledge design environment, quite general conclusions are formulated explaining both the macroscale of cross-cultural interaction, as well as processes taking place at the microsocial level of the formation of scientific teams and closed communities of scientists, for which, in the absence of rigorous quantitative tools and clear predictions, these complex approaches are often criticised.

3 . These approaches to the study of the social aspects of the phenomenon of science turn out to be at the same time complementary and mutually exclusive. Within the theoretical framework of scientists studying the interaction, the question of the content of generated scientific knowledge remains 
behind the scenes (it is often understood as a priori true and objective, despite it being clear that not all the actual products of "scientific" labour conform to this description). In line with the second approach, when it is precisely the specificity of the collective production of knowledge and the dependence of its contents on communicative reality that is the object of study, there is a tendency to blur the boundaries of the subject of cognition, resulting in a relativisation of the truth. Furthermore, as for example in the humanities - philology, cultural studies, history, etc. - it seems perverse to refuse to be scientific on the basis of a lack of mathematical apparatus, experimentation or objectivity. Nevertheless, it is evident, on the one hand, that it is not only scientists, but also people who lack the official status of a scientist, who "do" science (i.e. strive to create genuine new knowledge); on the other hand, one cannot speak of the complete determination of knowledge by the social context, since a true scientist seeks and observes truth, even if expressing it in a special scientific language only comprehensible to his or her specialised community. Under conditions of necessity, the problem arises of how to choose between these theoretical and methodological systems - on the one hand, to embrace the processes occurring at the micro-, meso- and macro-social levels, and on the other, in a unified manner, clearly and in accordance with the phenomena of reality (and not idealised schemas), to understand the essence of the systems of organisation of science in their real, multifaceted socio-cultural being. Of course, this does not take away the significance of previous studies; on the contrary, it allows us to find productive ideas and findings in each of them. In an attempt to balance between these two prevailing views, we posed the question: What is the sole prior condition, in the absence of which a given activity may not be termed 'science'? And we have concluded that science is only possible in the presence of theory. If science lacks a theoretical basis, then any mathematical calculations will remain an empty abstraction, experimental data will be baseless and objective laws will be scattered into fragments of private ideas. An understanding of science as "the theory of the real" (Heidegger) makes it possible to simultaneously demarcate its boundaries as a specific type of human activity, as well as to provide a rationale for the substantive differences between its various cultural and historical subtypes.

We are of the view that all three outlined aspects of the consideration of science have methodological potential; however, with contextual limits being placed on their application in each case. Thus, for example, when studying contemporary scientific criteria or planning a natural scientific and /or technical research project, it may be convenient to use the experimental-mathematical ap- 
proach to rational enquiry. Conversely, if the goal is to investigate the historical transformations of the content of knowledge, the differences in the social organisation of the sphere of science, as well as its isolation from or fusion with other activities in a particular culture, then it may make more sense to interpret science in a broader sense as a system of knowledge and cognitive activity taking place within a particular human society. Finally, if we consider the essence of science not just as a set of knowledge and cognitive techniques, not only as a system constructed in the language of mathematics and empirical research, but as something that is impossible outside the realms of theory, then a rather productive third perspective of the study of the phenomenon of science appears. This perspective takes into account both the socio-cultural conditionality of the content of scientific knowledge, arranged in the form of mental contemplation (theory), as well as the historical specificity of the transformation of ideas, social structures, cultural principles, language and methods, within which science develops as a living, paradoxical - at the same time unique and universal - phenomenon. In future work, we will consider some of the practical consequences of a failure to resolve the Eurocentric and culture-specific interpretations of science in the context of post-Soviet Russia's strategic aim to integrate its science with the rest of the world given the growing dominance of English and associated problem of "linguistic imperialism".

\section{References}

1. Latour B. Science in action: How to follow scientists and engineers through society. Cambridge, Massachusetts: Harvard University Press; 1987.

2. Foucault M. The order of things: An archaeology of the human sciences. London, New York: Routledge; 2002.

3. Robert K. Merton. Sociology of science and Sociology as science [Internet]. Ed. by Craig Calhoun. Columbia University Press/SSRC; 2010 [cited 2018 Sep 05]. Available from: http://cup.columbia.edu/book/978-0-231-151122 /robert-k-merton

4. Merton R. K. The Matthew effect in science, II. Cumulative advantage and the symbolism of intellectual property. ISIS. 1988; 79: 606-623.

5. Bloor D. Knowledge and social imagery. 1st edition. London: Routledge; 1976.

6. Habermas J. Technology and science as 'ideology'. Toward a rational society: Student protest, science, and politics. Boston: Beacon Press; 1971. p. 81-122.

7. Fuller S. Customized science as the reflection of 'protoscience'. Epistemology and Philosophy of Science. 2015; XLVI(4): 52-69.

8. Etzkowitz H. Entrepreneurial scientists and entrepreneurial universities in American academic science. Minerva. 1983; 21: 198-233.

9. Antonovskii A. Yu. Communicative interpretation of science in the context of classical epistemological problems. Epistemology \& Philosophy of Science. 2016; 18(2): 159-175. (In Russ.)

Образование и наука. Том 20, № 9. 2018/The Education and Science Journal. Vol. 20, № 9. 2018 
10. Bakeeva E. V. Modern science: Reflectivity and localisation. Nauchnyi ezhegodnik Instituta filosofii i prava Ural'skogo otdeleniya Rossiiskoi akademii nauk $=$ Research Yearbook. The Institute of Philosophy and Law. Ural Branch of the Russian Academy of Sciences. 2014; 14(4): 22-34. (In Russ.)

11. Biricheva E. V. Social'naja kommunikacija v sfere nauki = Social communication in the sphere of science. Upravlenie i kommunikatsii: analiz tendentsii i perspektivy razvitiya $=$ Management and communication: Analysis of trends and perspectives of development. Cheboksary; 2016. p. 39-46. (In Russ.)

12. Bryanik N. V. Samobytnost' russkoj nauki: predposylki i real'nost' = Originality of Russian science: Factors and reality. Ekaterinburg; 1994. (In Russ.)

13. Bucheister J. Toward a theory of academic self-awareness. Teaching and learning together in higher education [Internet]. US: Scholarship, Research, and Creative Work at Bryn Mawr College; 2016 [cited 2016 Oct 12]. Available from: http://repository.brynmawr.edu/tlthe/vol1/iss 12/ 1

14. Chernikova I. V., Chernikova D. V. The new concept of knowledge production in technoscience. Vestnik Tomskogo gosudarstvennogo universiteta. Filosofija. Sociologija. Politologija = Tomsk State University Journal of Philosophy, Sociology and Political Science. 2017; 39: 48-58. DOI: 10.17223/1998863X/39/6 (In Russ.)

15. History of artificial cold, scientific, technological and cultural issues [Internet]. K. Gavroglu (Ed.). Boston Studies in the Philosophy and History of Science / ed. by A. Bokulich, R. Cohen, J. Renn, K. Gavgorlu. Vol. 299. Springer; 2014 [cited 2018 Sep 05]. Available from: http://www.springer.com/series /5710

16. Kasavin I. T. Predmet i metody social'noj jepistemologii $=$ Subject and methods of social epistemology. Yazyk, znanie, sotsium: Problemy sotsial'noi epistemologii = Language. Knowledge. Society: Problems of social epistemology. Moscow; 2007. p. 3-13. (In Russ.)

17. Perovic S., Radovanovic S., Sikimic V., Berber A. Optimal research team composition: Data envelopment analysis of Fermilab experiments. Scientometrics. 2016; 108: 83-111.

18. Popova N., Moiseenko Ya., Beavitt T. Conformity in modern science: An engine of societal transformation? Changing Societies \& Personalities. 2017; 1 (3): 237-258. DOI: http://dx.doi.org/10.15826/csp.2017.1.3.017

19. Popova N. G., Beavitt T. A. English as a means of scientific communication: Linguistic imperialism or interlingua? Integraciya obrazovaniya = Integration of Education. 2017; 21(1/86): 54-70.

20. Popova N. G., Biricheva E. V. Purpose-oriented approach to the reader's assessment of the quality of research papers. Monitoring of Public Opinion: Economic and Social Change [Internet]. 2018 [cited 2018 Sep 05]. 4: 148-168. Available from: https://doi.org/10.14515/monitoring.2018.4.09

21. Romanovskaya T. B. K analizu ponjatija "nacional'naja nauka»: postanovka problemy = To the analysis of the concept "national science": Problem statement. Sotsiokul'turnyi kontekst nauki = Sociocultural Context of Science. Moscow: Institute of Philosophy, Russian Academy of Sciences; 1998. p. 70-83. (In Russ.) 
22. Walsh J., Lee Y. The bureaucratization of science. Research Policy. 2015; 44: 1584-1600.

23. Kant I. Critique of Pure Reason. New York: Cambridge University Press; 1998.

24. Marx K. The German Ideology [Internet]. [cited 2016 Aug 30]. Available from: https://www.marxists.org/archive/marx/works/1845/german-ideology/ch01b.htm

25. Kant I. Critique of Practical Reason. Indianapolis, Cambridge: Hackett Publishing Company; 2002.

26. Comte A. Course of Positive Philosophy [Internet]. [cited 2018 Sep 05]. Available from: http://www.historyguide.org/intellect/comte_cpp.html

27. Heidegger M. Overcoming of Metaphysics. In: The End of Philosophy. Chicago: The University of Chicago Press; 2003. p. 84-111.

28. Husserl E. The Crisis of European sciences and transcendental phenomenology. Evanston: Northwestern University Press; 1970.

29. Chernozub S. P. The concept of national science in a new discourse of civilizations. Istoricheskaya psikhologiya $i$ sotsiologiya istorii = Historical Psychology and Sociology of History. 2012; 1: 43-61. (In Russ.)

30. Gadamer H.-G. Istorija ponjatij kak filosofija = History of notions as philosophy. Aktual'nost' prekrasnogo $=$ Relevance of beauty. Moscow; 1991. p. 26-43. (In Russ.)

31. Descartes R. Principles of Philosophy. Dordrecht, Boston, London: Kluwer Academic Publishers; 1991.

32. Lévi-Strauss C. Structural Anthropology. New York: Doubleday Anchor Books; 1967.

33. Feyerabend P. Against Method. 4th ed., New York: Verso Books; 2010.

34. Ortega y Gasset J. History as a system and other essays toward a philosophy of history. New York; London: Norton \& Company; 1962.

35. Polanyi M. Personal knowledge: Towards a post-critical philosophy. University of Chicago Press; 1958.

36. Weber M. Science as a vocation [Internet]. [cited 2018 Sep 05]. Available from: http://anthropos-lab.net/wp/wp-content/uploads/2011/12/Weber-Science-as-a-Vocation.pdf

37. Meillassoux Q. After Finitude: An essay on the necessity of contingency. Continuum; 2008.

38. Mamardashvili M. K. Prostranstvo mysli $i$ jazyk filosofii = Space of thought and the language of philosophy. Filosofskie chteniya = Philosophical readings. Saint-Petersburg; 2002. p. 62-78. (In Russ.)

39. Heisenberg W. Abstrakcija $v$ sovremennoj nauke $=$ Abstraction in the contemporary science. Shagi za gorizont = Steps beyond the horizon. Moscow; 1987. p. 241-257. (In Russ.)

40. Heidegger M. Science and reflection. The question concerning technology and other essays. New York; London: Garland Publishing; Inc; 1977: 155-182.

41. Parmenides. On Nature [Internet]. [cited 2018 Sep 05]. Available from: http://www.platonic-philosophy.org/files/Parmenides\%20-\%20Poem.pdf

42. Aristotle. Metaphysics. London: Henry G. Bohn; 1857. 


\section{Список использованных источников}

1. Latour B. Science in Action: How to Follow Scientists and Engineers Through Society. Cambridge, Massachusetts: Harvard University Press, 1987.

2. Foucault M. The Order of Things: An Archaeology of the Human Sciences. London; New York: Routledge, 2002.

3. Robert K. Merton: Sociology of Science and Sociology as Science (2010) / ed. by Craig Calhoun. Columbia University Press / SSRC. Available at: http://cup.columbia.edu/ book/978-0-231-15112-2/robert-k-merton (дата обращения: 5.09.2018).

4. Merton R. K. The Matthew Effect in Science, II // Cumulative Advantage and the Symbolism of Intellectual Property. ISIS. 1988. № 79. P. 606-623.

5. Bloor D. Knowledge and Social Imagery, 1st edition. London: Routledge, 1976.

6. Habermas J. Technology and Science as 'Ideology'. In: Toward a Rational Society: Student Protest, Science, and Politics. Boston: Beacon Press, 1971. P. 81-122.

7. Fuller S. Customized Science as the Reflection of 'Protoscience' // Epistemology and philosophy of science. 2015. Vol. XLVI, № 4. P. 52-69.

8. Etzkowitz H. Entrepreneurial scientists and entrepreneurial universities in American academic science // Minerva. 1983. № 21. P. 198-233.

9. Антоновский А. Ю. Коммуникативная интерпретация науки в контексте классических эпистемологических проблем // Epistemology \& Philosophy of Science. 2016. T. XVIII, № 2. C. 159-175.

10. Бакеева Е. В. Современная наука: рефлексивность и "мокализация" // Научный ежегодник Института философии и права Уральского отделения Российской академии наук. 2014. Т. 14. Вып. 4. С. 22-34.

11. Биричева Е. В. Социальная коммуникация в сфере науки // Управмение и коммуникации: анализ тенденций и перспективы развития. Чебоксары, 2016. С. 39-46.

12. Бряник Н. В. Самобытность русской науки: предпосылки и реальность. Екатеринбург, 1994.

13. Bucheister J. Toward a theory of academic self-awareness. Teaching and Learning together in Higher Education. US: Scholarship, Research, and Creative Work at Bryn Mawr College. 2016. Available from: http:// repository.brynmawr. edu/tlthe/vol1/iss 12/1 (дата обращения: 12.09.2016).

14. Черникова И. В., Черникова Д. В. Новая концепция производства знания в технонауке // Вестник Томского государственного университета. Фимософия. Социология. Политология. 2017. № 39. C. 48-58. DOI: 10.17223/1998863X/39/6.

15. History of Artificial Cold, Scientific, Technological and Cultural Issues / K. Gavroglu (Ed.). Boston Studies in the Philosophy and History of Science. A. Bokulich, R. Cohen, J. Renn, K. Gavgorlu (Eds.). Vol. 299. Springer; 2014. Available from: http://www.springer.com/series/5710 (дата обращения: 5.09.2018).

16. Касавин И. Т. Предмет и методы социальной эпистемологии // Язык, знание, социум: Проблемы социальной эпистемологии. Москва, 2007. C. 3-13. 
17. Perovic S., Radovanovic S., Sikimic V., Berber A. Optimal research team composition: data envelopment analysis of Fermilab experiments. Scientometrics. 2016; 108: 83-111.

18. Popova N., Moiseenko Ya., Beavitt T. Conformity in Modern science: An Engine of Societal Transformation? Changing Societies \& Personalities. 2017, № 1 (3). P. 237-258. DOI: http://dx.doi.org/10.15826/csp.2017.1.3.017.

19. Popova N. G., Beavitt T. A. English as a Means of Scientific Communication: Linguistic Imperialism or Interlingua? // Integraciya obrazovaniya. 2017. № 21 (1/86). P. 54-70.

20. Попова Н. Г., Биричева Е. В. Целеориентированный подход к оценке качества научных публикаций читателем // Мониторинг общественного мнения: Экономические и социальные перемены. 2018. № 4. С. 148-168. https://doi.org/10.14515/monitoring.2018.4.09.

21. Романовская Т. Б. К анализу понятия "национальная наука": постановка проблемы // Социокультурный контекст науки. Москва, 1998. С. 70-83.

22. Walsh J., Lee Y. The bureaucratization of science // Research Policy. 2015. № 44. P. 1584-1600.

23. Kant I. Critique of Pure Reason. New York: Cambridge University Press, 1998.

24. Marx K. The German Ideology. Available from: https://www.marxists.org/ archive/marx/works/1845/german-ideology/ch01b.htm (дата обращения: 30.08.2016).

25. Kant I. Critique of Practical Reason. Indianapolis, Cambridge: Hackett Publishing Company, 2002.

26. Comte A. Course of Positive Philosophy. Available from: http:// www.historyguide.org/intellect/comte_cpp.html (дата обращения: 5.09.2018).

27. Heidegger M. Overcoming of Metaphysics. In: The End of Philosophy. Chicago: The University of Chicago Press; 2003: 84-111.

28. Husserl E. The Crisis of European Sciences and Transcendental Phenomenology. Evanston: Northwestern University Press, 1970.

29. Чернозуб С. П. Концепт национальной науки в новом дискурсе цивимизаций // Историческая психология и социология истории. 2012. № 1. С. 43-61.

30. Гадамер Г.-Г. История понятий как фияософия // Гадамер Г.-Г. Актуальность прекрасного. Москва, 1991. С. 26-43.

31. Descartes R. Principles of Philosophy. Dordrecht, Boston, London: Kluwer Academic Publishers; 1991.

32. Lévi-Strauss C. Structural Anthropology. New York: Doubleday Anchor Books; 1967.

33. Feyerabend P. Against Method. 4th ed. New York: Verso Books; 2010.

34. Ortega y Gasset J. History as a System and Other Essays Toward a Philosophy of History. New York; London: Norton \& Company; 1962.

35. Polanyi M. Personal Knowledge: Towards a Post-Critical Philosophy. University of Chicago Press; 1958. 
36. Weber M. Science as Vocation. Available from: http://anthroposlab.net/ wp/wp-content/uploads/2011/12/Weber-Science-as-a-Vocation.pdf (дата обращения: 5.09.2018).

37. Meillassoux Q. After Finitude: An Essay On The Necessity Of Contingency. Continuum; 2008.

38. Мамардашвили М. К. Пространство мысли и язык философии // М. К. Мамардашвили. Фимософские чтения. Санкт-Петербург, 2002. С. 62-78.

39. Гейзенберг В. Абстракция в современной науке // В. Гейзенберг. Шаги за горизонт. Москва, 1987. С. 241-257.

40. Heidegger M. Science and Reflection // The Question Concerning Technology and Other Essays. New York; London: Garland Publishing; Inc, 1977. P. 155-182.

41. Parmenides. On Nature. Available from: http://www.platonic-philosophy.org/files/Parmenides\%20-\%20Poem.pdf (дата обращения: 5.09.2018).

42. Aristotle. Metaphysics. London: Henry G. Bohn, 1857.

Information about the authors:

Natalia G. Popova - PhD (Sociology), Senior Researcher, Sector of Theoretical Linguistics and Academic Communications, Departmental Head, Department of Foreign Languages, Institute of Philosophy and Law, Ural Branch of the Russian Academy of Sciences; ORCID: 0000-0001-7856-5413; Ekaterinburg, Russia. E-mail:ngpopova@list.ru

Ekaterina V. Biricheva - PhD (Philosophy), Researcher, Sector of History and Philosophy of Science, Institute of Philosophy and Law, Ural Branch of the Russian Academy of Sciences; ORCID: 0000-0003-1933-9955; Ekaterinburg, Russia. E-mail: e.v.biricheva@mail.ru

Thomas A. Beavitt - Researcher, Sector of Theoretical Linguistics and Academic Communications, Institute of Philosophy and Law, Ural Branch of the Russian Academy of Sciences; The 'Global Village Bard' Organisation; ORCID: 00000002-3391-2167; Ekaterinburg Russia; UK. Email: tommy@globalvillagebard.org

\section{Contribution of the authors:}

E. V. Biricheva developed the concept and argumentation, studied the literature sources and wrote the first draft of the manuscript.

N. G. Popova participated in the discussion of the concept and logic of argumentation, investigated the existing literature, worked on the Russian-language text of the manuscript, discussed and worked on the translation of the manuscript into English.

T. A. Beavitt participated in the discussion of the concept and logic of argumentation, translated, edited and proofread the final version of the text.

Received 11.07.2018; accepted for publication 17.10.2018.

The authors have read and approved the final manuscript. 


\section{Ннформаиия об авторах:}

Попова Натамья Геннадьевна - кандидат социологических наук, старший научный сотрудник Сектора теоретической мингвистики и академических коммуникаций, заведующая кафедрой иностранных языков Института философии и права Уральского отдемения PAH; ORCID: 0000-0001-78565413; Екатеринбург, Россия. E-mail: ngpopova@list.ru

Биричева Екатерина Вячеславовна - кандидат философских наук, научный сотрудник Сектора истории и философии науки Института философии и права Уральского отделения PAH; ORCID: 0000-0003-1933-9955; Екатеринбург, Россия. E-mail: e.v.biricheva@mail.ru

Бивитт Томас А^ександр - научный сотрудник Института фимософии и права Уральского отдемения PAH; ORCID: 0000-0002-3391-2167; Екатеринбург, Россия; The 'Global Village Bard' Organisation, Russia-UK. Email: tommy@globalvillagebard.org

\section{Вклад соавторов:}

Е. В. Биричева разрабатывала концепцию, выстраивала могику аргументации на основании изучения списков митературы и принимала участие в создании рукописи статьи.

Н. Г. Попова участвовала в обсуждении концепции работы и могики аргументации, изучении митературных источников, доработке текста и переводе русскоязычного текста на английский язык.

Т. А. Бивитт принимал участие в обсуждении основных концептуальных положений, переводе текста на английский язык и его последующем редактировании.

Статья поступила в редакцию 11.07.2018; принята в печать 17.10.2018. Авторы прочитали и одобрили окончательный вариант рукописи. 